\title{
'Struggle For Power In Tourism Supply Chain Management At Goa Pindul Karst Area, Indonesia
}

\author{
Victoria Sundari Handoko, Susetiawan, Muhammad Supraja.
}

\begin{abstract}
The rapid development of tourism villages in the Special Region of Yogyakarta, Indonesia, represents the transformation of villages into modern villages. Bejiharjo Village, one of tourism villages in Indonesia, seeks to implement tourism industrialization by improving the village competitive advantages despite the traditional community life. One of the strategies of the tourism village in improving its competitiveness is the implementation of effective Tourism Supply Chain Management (TSCM). Tourism Groups (pokdarwis) of Dewa Bejo have been appointed by Bejiharjo Village Government to manage the village tourism destination by implementing the strategy. However, the implementation faced some obstacles due to the struggle of power involving the tourism groups which compete to obtain control over the management of Goa Pindul Karst Area. The main issues addressed in this research are the way the struggle for power among the groups becomes an obstacle in supply chain management and the possible solutions for such a problem. The ethnographic research employed observations and in-depth interviews with 11 tourism groups and the village government. The findings reveal that the struggle for power among the groups has become the main obstacle in the optimization of tourism supply chain management. The role of the government and the involvement of various parties are needed for addressing and overcoming the struggle for power so that more effective supply chain management can be realized for improving tourism.
\end{abstract}

Index Terms: Keywords: tourism village, Goa Pindul Karst Area, struggle for power, tourism supply chain management.

\section{INTRODUCTION}

According to the data from the Statistics Indonesia, 2008, Indonesia is home to 1,734 tourist villages. The development of a rural area into a tourist village makes transform the area into a modern village where the penetration of new businesses introduce to the villagers fresh lifestyles and values. This village modernization, however, bears an oxymoron concept, that is, the "noble" offering and purpose of engaging the community in poverty alleviation comes with a struggle for power among multiple actors. This is the case in the Bejiharjo Tourist Village, where tourism awareness groups are fighting over the management of tourism services businesses existing around Pindul Cave Karst, the village's favorite tourist destination.

Revised Manuscript Received on April 19, 2019.

Victoria Sundari Handoko, Department of Sociology, Universitas Atma Jaya Yogyakarta, Yogyakarta, Indonesia.

Susetiawan, Department of Social Development and Welfare, Universitas Gadjah Mada, Yogyakarta, Indonesia.

Muhammad Supraja, Department of Sociology, Universitas Gadjah Mada, Yogyakarta, Indonesia.
The Pindul Cave Karst area in Bejiharjo Tourist Village, Gunungkidul, has been a main tourist destination famed locally, even internationally. The development of Pindul Cave Karst area with its cave tubing inspired the Bejiharjo Village government to further develop the village into a tourist village back in 2010. Two years later, Bejiharjo Tourist Village won the Best Tourist Village Award from the Ministry of Tourism and Creative Economy.

With the award won in 2012, the village government along with the community was considered able to enhance the village's tourism quality through community empowerment. The presence of a tourist village is deemed able to overcome poverty, create jobs, and propel the economy of village people. However, Bejiharjo Tourist Village has paved a way to a struggle for power among tourism awareness groups (pokdarwis) with respect to its management. Early in the tourist village's establishment (2010), there was only a single pokdarwis that existed namely Dewa Bejo, but later this number rose to 11 with the increase of national and international visits every year.

This struggle for power in the management of Pindul Cave Karst area, Bejiharjo Tourist Village, started in 2012 and was still ongoing when this paper was made (2019). This struggle for power between tourism awareness groups sets an impediment to the efficiency of tourism supply chain to tourists. The main questions posed in this research, thus, are as follows: How does the struggle for power between tourism awareness groups present an impediment to the supply chain management? How should the supply chain management be constructed to improve its effectiveness?

The existing studies of supply chain management majorly focused on the manufacturing industry, and little did they focus on the service industry, let alone water tourism services and struggle for power to be the manager of the water tourism services in Pindul Cave Karst area, Bejiharjo Tourist Village. Solutions to this problem of struggle for power are sought to improve the competitive advantages of, and maintain the comfort for tourists visiting, Bejiharjo Tourist Village. The tourism awareness groups in Bejiharjo Tourist Village can work together and, with support from competent government agencies, optimize the tourism supply chain management (TSCM). 


\section{LITERATURE REVIEW}

Supply chain management, according to Hugos, is the coordination of production, inventory, location, and transportation among the participants in a supply chain to achieve the best mix of responsiveness and efficiency for the market being served [1]. Hugos states that the goal of supply chain management is to increase sales of goods and services to the final, end use customer while at the same time reducing both inventory and operating expenses [1]. Furthermore, Russel and Taylor [2] add that supply chain management requires managing the flow of information through the supply chain in order to attain level of synchronization that will make it more responsive to customer needs while lowering cost.

Consumers in supply chain management receive priority because they are purchasers or receivers of products or buying service or other kinds of services. Hugos stresses that the supply chain and the organizations in it are a single entity. This systems approach provides the framework in which to best respond to business requirements that otherwise would seem to be in conflict with each other [1]. In the practice, however, this supply chain cannot evade conflictual situations due to clashing demand and interests [1].

Zhang et al. [3] say that the tourism sector is characterized by different activities, but also closely linked to the production of the final service. This, according to Song et al., is due to tourism supply chain emergance that the network partners of such tourism network are defined beyond traditional supply chain boundaries and consist of a range of entities such as tourists, companies that act as service providers and intermediaries, government agencies, regulators, technology providers, communities, and consultants [4]. A tourism supply chain (TSC) according to Zhang, Song, and Huang can be defined as a network of tourism organizations supplying different components of tourism products/services such as flights and accommodation for the distribution and marketing of the final tourism products at a specific tourism destination, and involves a wide range of participants in both the private and public sectors [3].

Conflictual relation related to struggle for power between agents in supply chain management also occurs in the tourism sector. Chen et al. say that conflict can be divided into each enterprise internal conflicts, the same node conflict between enterprises and adjacent nodes conflict between enterprises in the supply chain. There are four main types of conflict in supply chain: First, conflict between suppliers and suppliers; Second, conflict between suppliers and manufacturers; Third, conflict between dealers and dealers; and Fourth, conflict between dealers and manufacturers [5].

The conflict arising in the tourism supply chain management studied in this research was related to the struggle for power between actors in water tourism service management. Struggle for power itself, according to Bourdieu, aims to gain power and establish a set of norms and symbols, heterodoxy or orthodoxy. In the case of no competition, it is highly unlikely that struggle should happen [6]. Struggle emerges between collectivities as a support for heterodoxy against orthodoxy and brings sociocultural changes [6].
The actors controlling the resources (capital) existing in the community hold power over others. Those in power tend to act by reproducing their profits and attempt to build public trust by giving them privilege [7]. With regard to natural resources, a free market will give rise to a struggle between those with greater accumulated capital (dominant) and those with little or no capital at all. Thus, social inequality and domination of one actor over the other strongly influences the emergence of resistance from the victim and social struggle between actors.

In the tourism sector, the social actors involved in tourism activities come with varying interests and often present contrasting positions [8]. Such contrasting positions in many cases lead to a struggle for power in the tourism sector. Struggle for power often happens between local and foreign stakeholders, local elites, and government (state) in the management. This problem occurs because of the control over natural capital and land use, income distribution, and profits by the tourism business owners and potentially causes sidelining and marginalization of local communities [9]. The struggle for power between agents in the tourism sector sets an impediment to tourism supply chain management, and in this case, it disrupts the water tourism services and, eventually, tourist comfort.

\section{RESEARCH METHODS}

This research is an ethnographic study under a qualitative approach. The selection of this type of study was based on several reasons: First, struggle between agents happened naturally over a long period of time and involved multiple research subjects; Second, the struggle for power that had been going on since 2012 until this paper was written-the struggle for power between tourism awareness groups and tourism business groups-hindering the tourism service supply chain to tourists. It was deemed necessary to conduct an in-depth study analyzing the hindrances to the moreefficient Pindul Cave Karst water tourism services provision for tourists. Hence, data exploration by in-depth interviews and observations was carried out; and Third, research reality had to be unveiled in detail so the researchers could explore and research the social and cultural lives of the community, which made an essential part of the experiences of the agents involved in the struggle for power. This research was not aimed at generalizing the research results.

Inductive logic was employed in this research. This logic ontologically requires a dialogic process that expects researchers to collaborate and consider the research subjects experts in understanding problems in tourism supply chain management. The researchers learnt such problems from the research subjects and analyzed how they were solved.

Data collection was conducted by observations and indepth interviews. The researchers conducted in-depth interviews with the government official of Gunungkidul Regency, government official of Bejiharjo Village, and managers of 11 tourism awareness groups (pokdarwis) of Bejiharjo Tourist Village. The results from the observations and in-depth interviews help the researchers analyze the 
tourism supply chain management of Pindul Cave Karst water tourism.

The data collection, processing, and analysis processes were undertaken through an interactive cycle, where the researchers collected data and conducted analysis at the same time. A process with such cycle will last until the research is considered over. The analysis involved the processing, organizing, break-down, and synthesis of data as well as search of pattern, disclosure of key matters, and definition related to the research theme, namely the struggle for power in tourism supply chain management.

\section{RESULTS AND FINDING}

\section{A. Struggle for Power Between Pokdarwis}

Aside from Dewa Bejo, two other tourism awareness groups operating from 2010 to 2012 were Wira Wisata and Panca Wisata. The rising number of tourists and new tourism awareness groups established motivated owners of land in Pindul Cave area to form Taruna Wisata. However, the plan of establishing Taruna Wisata garnered disagreement and opposition from the community for no prior socialization and its unwillingness to work with the existing tourism awareness groups.

The struggle for power between the existing tourism awareness groups and owners of land over Pindul Cave as well as Taruna Wisata, whose establishment was successfully thwarted, has been ongoing. All the while, new tourism awareness groups kept on springing since 2013. The new tourism awareness groups that served the same destination of preference (Pindul Cave) intensified the struggle for power among all tourism awareness groups to a greater extent.

Then, the Gunungkidul Regency government came to a responsible for its respective tourist destination, one group for one tourist destination. As Pindul Cave sits in an area that covered two hamlets, Gelaran Hamlet and Gunungbang Hamlet, it comes under the responsibility of four different tourism business groups: Dewa Bejo, Wira Wisata, Panca Wisata, and Tunas Wisata. On that account, the government issued a policy to merge the four groups (Dewa Bejo being Dewa Bejo 1, Wira Wisata being Dewa Bejo 2, Panca Wisata being Dewa Bejo 3, and Tunas Wisata being Dewa Bejo 4). The four pokdarwis grew dominant and held the power to grant tourist the entry to Pindul Cave. The remaining pokdarwis had to ask for permission from either of the four to admit tourists. The following are the tourism awareness groups (pokdarwis) names, its location, year of establishment, and tourist destination under its responsibility (10).

Table 1 Tourism Business Groups being Dewa Bejo 1, 2,3 , and 4

\begin{tabular}{|c|l|l|l|}
\hline Number & \multicolumn{1}{|c|}{ Pekdecoris Name } & \multicolumn{1}{|c|}{ Hamlet } & $\begin{array}{c}\text { Tourist } \\
\text { Destination }\end{array}$ \\
\hline 1 & Dewa Bejo or Dewa Bejo 1 & Gelaran 1 & Rindul Cate \\
\hline 2 & Wira Wisata or Dewa Bejo 2 & Gelaran II & Bindul Cave \\
\hline 3 & Panca Wisata or Dewa Bejo 3 & Gelaran I & Pindul Cave \\
\hline 4 & Tunas Wisata or Dewa Bejo 4 & Gununghang & Rindul Cave \\
\hline
\end{tabular}

Sources: Interviews with administrators of pokdarwis $1,2,3$, and 4 decision that every tourism business group was to be

The tourism business groups in Bejiharjo Tourist Village experienced some changes in development: First, four pioneering tourism business groups, Dewa Bejo, Wira Wisata, Tunas Wisata, and Panca Wisata merged into Dewa Bejo 1, 2, 3, and 4. Second, one tourism business group, Panji Wisata, quitted from the business. Panji Wisata was established on July 7, 2013 and ceased from business in the following year because its human resource was inferior to that of other hamlets' tourism business groups who were younger and better in promoting their respective business groups. Besides, there was another challenge presented by brokers (informal marketers getting in tourists' way to the Pindul Cave area). Third, there emerged six new other tourism business groups that used Pindul Cave as their main tourist destination, namely Mriwis Putih, Karya Wisata, Dewi Taliman, Gelaran Indah, Sumber Banyu Moto, and Ngancar Wisata. These groups subsequently formed the Tourism Operators Association (POW).

The POW was a subordinate group to the dominant group, Dewa Bejo 1, 2, 3, and 4. It became subordinate as a result of the government policies. The dominating tourism business group was favored by the Gunungkidul Regency government in the development of Bejiharjo Tourist Village thanks to its community empowerment program bias. This bias was a result from the Regulation of the Minister of Culture and Tourism Number KM.18/HM.001/MKP/2011 on the Guideline on the National Community Empowerment Program (PNPM Mandiri) in Tourism. The following is a table of groups making up the POW (10).

Table 2: The Groups Making Up the Tourism Operators Association (POW)

\begin{tabular}{|c|c|c|c|c|}
\hline Number & Groep Xamer & Hamint & Estathlinmeat & Taurist Dentieatina \\
\hline 1 & Merwis Rak & Bucybering II & 2012 & Moval Rels Luls \\
\hline 2 & Karge wisat & Kascose & 3013 & Inticase \\
\hline 3 & Deritalinan & Sntulimin & 2014 & Sotoling Ste \\
\hline 4 & Gelarn labes & fecteras! & 2014 & Buscat \\
\hline 5 & $\begin{array}{l}\text { Scaher Buayn } \\
\text { Mots }\end{array}$ & Gelmat & 2315 & Gidicint \\
\hline 6 & 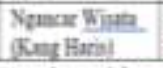 & Gelena ill & 2016 & Sogutcon \\
\hline
\end{tabular}

The subordinate group was required to set the price of the admission ticket to Pindul Cave at Rp10,000 per visitor. It forced the group to work multiple times as harder to finance its tourism service marketing as well as other services (11). The great number of rival groups competing each other and the lack of control in the pricing have led to price war. Many actors were involved in the Pindul Cave admission ticket price war, both formal and non-formal (e.g., brokers). Brokers took part in Pindul Cave admission ticket price war by offering tourists they won to any group that could give them more money. Aside from that, the rival groups cooperated with brokers by paying brokers who took tourists to their secretariat higher than the agreed price, Rp5,000. These freelance marketers were even dare to offer the Pindul Cave admission ticket to pokdarwis lower than the actual price, namely Rp35,000 per tourist. As a result, some groups 
were willing to cooperate, while the others were not.

In addition to cooperating with travel agents, the marketing of the existing groups was also performed by information technology. They promoted their tourism services via websites, Twitter, Facebook, and handphone. The intense competition for visitors or tourists inspired the marketers to use website for the marketing, for example giving a $20 \%$ discount. Any one of 20 tourists could take $20 \%$ off. The number of tourists receiving the discounts increased with every 20-tourist addition. The pokdarwis applying this strategy claimed that it was the only group that applied the $20 \%$ off strategy.

Asymmetrical or vertical relation such as this frequently brought about frictions between dominant and subordinate tourism business group. The dominated group or class, according to Bourdieu, "have an interest in pushing back the limits of doxa and exposing the arbitrariness of the taken for granted, whereas the dominant classes have an interest in defending [12]."

\section{B. More Egalitarian Tourism Supply Chain Construction}

The results of the preliminary study in the field in relation to the management of Pindul Cave area as a tourist destination show that the management was in the hand of the dominant group (Dewa Bejo) as the master of Pindul Cave "entrance". The remaining pokdarwis belonged to the subordinate group. The following is an illustration of the tourism supply chain in the dawn of Bejiharjo Tourist Village development.

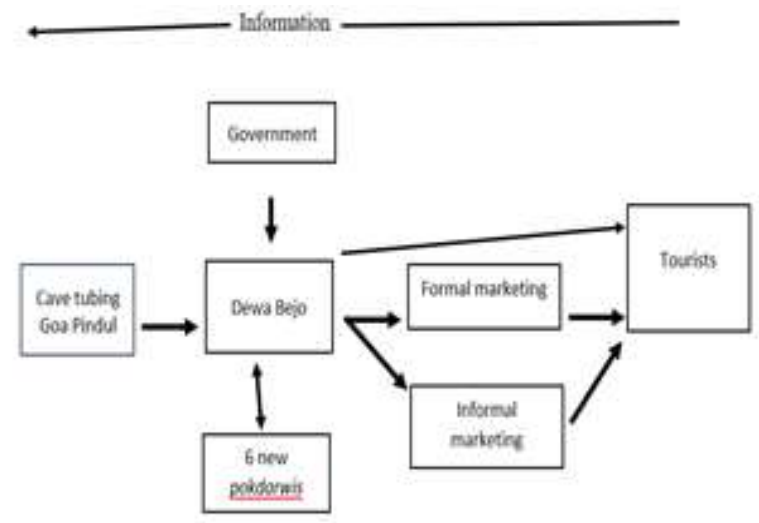

Fig. 1: Tourism Supply Chain in Pindul Cave Area

This supply chain management system has put the subordinate group at disadvantage in the water tourism service provision for tourists. The reason is that this subordinate group had to incur additional operating costs, for example, cooperation cost and marketing (formal and non-formal) marketing cost, causing its supply chain to be inefficient. This drove the subordinate group to struggle against its dominant counterpart as in refusing to cooperate and pay the dominant group the cooperation contribution. This struggle is a form of the struggle of the dominated or the disadvantaged, and it is incidental (epiphenomenal) and uncoordinated in nature. The struggle of the advantaged, according to Eckstein, needs only a little or even no coordination and they challenge the norms and domination of the elite in a direct manner. A struggle such as this may undermine the government's authority and productivity, so the political and economic elite find it necessary to make meaningful changes [13].

The six tourism business groups belonging to the POW urged the government to establish a Village-Owned Enterprise (BUMDes). It was expected to be able to band together the groups that had been struggling for power. It was aimed to create a conducive atmosphere and prosperity for all group members as opposed to individuals or just a couple of groups. This urging fruited the establishment of a BUMDes in 2017. BUMDes blurred the line between the dominant and subordinate group and promoted equity between all tourism awareness groups in an egalitarian way. The following is the illustration of the altered, more humanistic supply chain management in Bejiharjo Tourist Village:

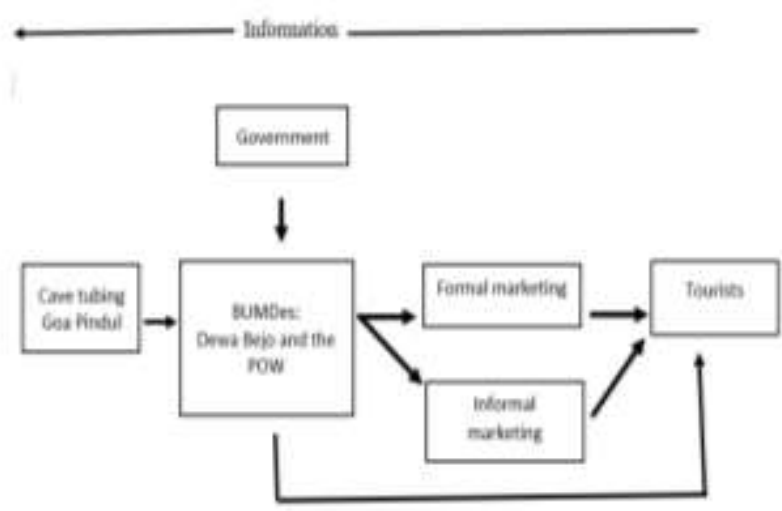

Fig. 2: More Egalitarian Relation between Pokdarwis in Tourism Supply Chain

The supply chain management as depicted in the diagram above placed all pokdarwis in an egalitarian system for two reasons: first, this system was better as it has eliminated the subordinate group that used to be compelled to work with the pioneering group and, second, a supply chain system such as this was able to manage the flow of water services in a supply chain. The government held the control over the relation between pokdarwis in the application of the supply chain, so with egalitarian SCM, it was able to apply the production and distribution network of Pindul Cave water tourism service package through the combined work of all components in maintaining the tourist comfort at Pindul Cave.

The government, partnering with all parties, managed to identify the impediment to the tourism supply chain in Pindul Cave Karst area, namely the struggle for power between pokdarwis, and then fix the system by putting into force the rules of the establishment of BUMDes in the village. These rules specified that all pokdarwis were under the BUMDes coordination, subordination between pokdarwis should be abolished, and so forth. These rules were obeyed by all pokdarwis involved in the tourism 
supply chain management. As a result, better efficiency in the work for tourist comfort was created. The heart of this system was the coordination between links as well as the ideas to maximize the performance for satisfaction between links and trust within the links.

\section{CONCLUSION}

The tourism supply chain management of the water tourism services of Pindul Cave Karst area could improve the effectiveness and efficiency of the flow of the tourism services (cave tubing) to local, national, and international tourists. The tourism supply chain management could identify an impediment in the service provision flow in the form of struggle for power for the water tourism services and the solutions to such impediment. The improvement of the existing system had an advantage, as in enabling the management of the flow of goods or products, in this case water tourism services, in supply chain management that positioned all pokdarwis equally.

\section{REFERENCES}

1. Hugos, M., Essentials of Supply Chain Management. 2003, New Jersey: John Wiley\&Sons,Inc.

2. Russell, R.S. and B.W. Taylor, Operations Management: Creating Value Along the Supply Chain. 2011, the United States of America JOHN WILEY \& SONS, INC.

3. Zhang, X., H. Song, and G.Q. Huang, Tourism supply chain management: A new research agenda. elsevier, 2009: p. 345-358.

4. Song, H., Jingyan Liu, and G. Chen, Tourism Value Chain Governance: Review and Prospects Journal of Travel Research, 2012: p. 96-107.

5. Chen, H., et al., Research on the Conflict Analysis of Supply Chain Management based on Graph Model with MRCR in 2nd International Conference on Software Engineering, Knowledge Engineering and Information Engineering (SEKEIE 2014) 2014, Atlantis Press Singapore. p. 57-61.

6. Lash, S., Sociology of Postmodernism. 1990, London: Routledge.

7. Andersen, M.L. and H.F. Taylor, Sociology: Understanding a Diverse Society. 2000, Amerika: Wadsworth.

8. Cañada, E., Tourism in Central America, Social conflict in a new setting. 2010, Managua: www.albasud.org

9. Bengi Ertuna, G.K., Local community involvement in rural tourism development: The case of Kastamonu, Turkey PASOS, 2012. 10 (2): p. 17-24.

10. Handoko, Victoria Sundari, The Power Struggle between Agent: Capital Placement Strategy in Goa Pindul Tourism Arena (Master's Dissertation), 2018, Retrieved from Electronic Thesis and Dissertations (ETD), Gadjah Mada University.

11. Handoko, Victoria Sundari, Domination Among Tour Operators in Karst Conservation Area of Goa Pindul, Indonesia. International Journal Economic in Emerging Economies, vol. 12, No.2, 2019: p. 175-181

12. Bourdieu, P., Language and Symbolic Power. 1995, Cambridge: Polity Press.

13. Eckstein, S., Power and Popular Protest: Latin American Social Movement. 1989, Barkeley: University of California Press.

\section{AUTHORS PROFILE}

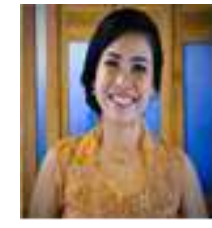

Dr. Victoria Sundari Handoko is currently working as lecturer in Sociology Study Program, Universitas Atma Jaya Yogyakarta, Indonesia. Her research interests in gender studies, conflict in tourism, health, rural dan urban area. She has over 23 years of experience in academics and research and is a member of ISI.

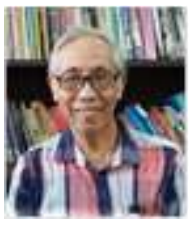

Prof. Dr. Susetiawan is currently working as lecturer in Department of Social Development and Welfare, Gadjah Mada Yogyakarta, Yogyakarta, Indonesia His research interests in social development, work and development, dan social development. He has over 38 years of experience in academics and research.

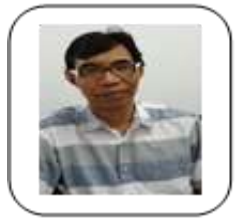

Dr. Muhammad Supraja is currently working as lecturer in Sociology Department, Universitas Gadjah Mada, Yogyakata, Indonesia. His research interests in critical discourse analysis, sociology of education, and sociology of religion. He has over 23 years of experience in academics and research and is a member of ISI. 